\title{
Climate-Driven Dietary Change on the Colorado Plateau, USA, and Implications for Gender-Specific Foraging Patterns
}

\author{
Lisbeth A. Louderback (D)
}

Complementary archaeological and paleoenvironmental datasets from North Creek Shelter (Colorado Plateau, Utah, USA) are analyzed using the diet breadth model, revealing human dietary patterns during the early and middle Holocene. Abundance indices are derived from botanical and faunal datasets and, along with stone tools, are used to test the prediction that increasing aridity caused the decline of high-return resources. This prediction appears valid with respect to botanical resources, given that high-ranked plants drop out of the diet after $9800 \mathrm{cal}$ BP and are replaced with low-ranked, small seeds. The prediction is not met, however, with respect to faunal resources: high-ranked artiodactyls are consistently abundant in the diet. The effects of climate change on dietary choices are also examined. Findings show that increased aridity coincides with greater use of small seeds and ground stone tools but not with increases in low-ranked fauna, such as leporids. The patterns observed from the North Creek Shelter botanical and faunal datasets may reflect different foraging strategies between men and women. This would explain why low-ranked plant resources became increasingly abundant in the diet without a corresponding decrease in abundance of high-ranked artiodactyls. If so, then archaeological records with similar datasets should be reexamined with this perspective.

Keywords: diet breadth model, broad spectrum diets, sexual division of labor, abundance indexes, macrobotanical remains, starch granules, tubers, ground stone tools, North Creek Shelter, Holocene

Se analizan, series de datos complementarios arqueológicos y paleo ambiéntales de la región norte, North Creek Shelter (Meseta del Colorado, Utah, Estados Unidos de America), utilizando el modelo de amplitud de la dieta alimentaria que revela el comportamiento alimenticio humano durante el Holoceno temprano y medio. Abundantes indices de datos botánicos y de fauna, así como de herramientas de piedra, comprueban la hipótesis de que el aumento de la aridez en la zona provocó la disminución de los recursos alimenticios de alto rendimiento. Esta predicción pareciera válida en relación a los recursos botánicos, ya que las plantas de alto rendimiento se eliminan de la dieta después de 9800 cal aP y son reemplazadas por semillas pequeñas de bajo rendimiento. Sin embargo, la predicción no se cumple con respecto a los recursos derivados de la fauna: los artiodáctilos de alto rendimiento son consistentemente abundantes en la dieta. También se examinan los efectos del cambio climático en las elecciones dietéticas, encontrando que el aumento de la aridez coincide con un mayor uso de semillas pequeñas y herramientas de piedra para moler, pero no con aumentos en la fauna de bajo rendimiento, como los lepóridos. Los patrones observados en las series de datos botánicos y de fauna de North Creek Shelter pueden reflejar diferentes formas de recolección de alimentos entre hombres y mujeres, lo que explica la discrepancia de que los recursos vegetales de bajo rendimiento se volvieron cada vez más abundantes en la dieta sin una disminución correspondiente en la abundancia de artiodáctilos de alto rendimiento. Basados en esta perspectiva, los hallazgos arqueológicos con series de datos similares deberían de reexaminarse.

Palabras clave: modelo de amplitud de la dieta, dietas de amplio espectro, división de labor por genero, índices de abundancia, residuos macrobotánicos, gránulos de almidón, tubérculos, herramientas de piedra para moler, North Creek Shelter, Holoceno

Lisbeth A. Louderback (lisbeth.louderback@ anthro.utah.edu, corresponding author) — Natural History Museum of Utah, Department of Anthropology, University of Utah, Salt Lake City, UT, USA

American Antiquity 87(1), 2022, pp. 1-17

Copyright (C) The Author(s), 2021. Published by Cambridge University Press on behalf of the Society for American Archaeology. This is an Open Access article, distributed under the terms of the Creative Commons Attribution licence (https://creativecommons.org/licenses/by/4.0/), which permits unrestricted re-use, distribution, and reproduction in any medium, provided the original work is properly cited.

doi:10.1017/aaq.2021.122 
$\mathrm{T}$ The ecology of broad spectrum diets has long been an issue in the prehistory of arid western North America. Broad spectrum diets have been described as energetically expensive, incurring high caloric costs in harvesting, processing, and preparing food materials for human consumption (Flannery 1969). Such diets included seed, insect, and small mammal components that required different technologies and social structures to provide sufficient caloric yields. This "broad spectrum revolution" of subsistence modification occurs around $9000 \mathrm{cal}$ BP in the Great Basin and Colorado Plateau and is associated with the intensive incorporation of small seed processing, basketry, and grinding stone technologies (Geib and Jolie 2018; Rhode et al. 2006; Simms 2008).

The hypothesis that has been most often proposed to explain this dietary pattern is drawn from optimal foraging theory, which suggests that people in general only resorted to low-return small seeds after calorically higherreturn resources and high-quality resource patches diminished in abundance (O'Connell et al. 1982). Based on the principles of the diet breadth (or prey choice) model (Stephens and Krebs 1986), food resources are ranked based on their expected post-encounter energetic return rates $(\mathrm{kcal} / \mathrm{hr})$ relative to other resources in the diet. Small seeds and other expensive plant resources are typically ranked low compared to large-bodied animals because of their high handling costs relative to energetic yields (Table 1). The diet breadth model predicts that foragers will always pursue higher-ranked resources on encounter and take lower-ranked resources only when encounter rates with higher-ranked resources decline (Schoener 1971). An increase in the abundance of lower-ranked resources in the diet therefore indicates a decline in the availability of high-ranked resources and an overall reduction in foraging efficiency (Bayham 1979; Broughton and Grayson 1993; Kelly 1995a; Winterhalder and Smith 1992).

This hypothesis, however, assumes an "average" or "undifferentiated" forager. It does not take into account differentiated and specialized roles in foraging strategies, such as age or gender, nor does it account for other hunting technologies (Hawkes and O'Connell 1992:64;
Jochim 1988:130; Kelly 2014; Sassaman 1992; Wood et al. 2021). These assumptions are important because the costs and benefits associated with reproductive fitness can differ between men and women (O'Connell et al. 1999). A more nuanced hypothesis (Elston and Zeanah 2002) suggests gender-specific foraging patterns across the Great Basin and Colorado Plateau during the early and middle Holocene. Whereas women foraged in local and reliable resource patches, accumulating low-return resources and investing heavily in plant-processing tools, men pursued fluctuating but highly mobile, large-bodied animals at some distance. It has also been suggested that variability in acquiring large game would lead to women foraging for lower-ranked resources (Elston et al. 2014).

Increasing aridity and vegetation responses have been offered as the ecosystem drivers of global changes in dietary patterns (e.g., Edwards and O'Connell 1995; O'Connell and Hawkes 1981, 1984; O'Connell et al. 1982; Rhode et al. 2006). In the Great Basin and Colorado Plateau specifically, dietary changes have been attributed to intense aridification that began at about 9500 cal BP (e.g., Grayson 2000, 2011; Louderback et al. 2020; O'Connell et al. 1982; Schmitt and Lupo 2012; Simms 2008). However, this paradigm of increasing aridity and dietary response has never been tested quantitatively using multiple lines of evidence from a single site. The current study applies the diet breadth model to understand human dietary patterns through time using the North Creek Shelter (NCS) faunal, botanical, stone tool, and climate datasets.

Although there are several types of measurable parameters used to examine diet breadth and foraging efficiency (e.g., evenness/richness, skeletal representation, age/sex ratio of faunal remains, climate, technology/tools, etc.), this study relies on abundance indexes constructed over time for faunal and botanical resources at NCS. These indexes, along with one for stone tools, are used to test the assumption that increasing aridity during the early to middle Holocene caused the decline of high-return resources and, therefore, led to the incorporation of low-return resources into the diets of the NCS occupants. To determine if diet breadth changes and/or a shift to low-return resources are coincident with 
Table 1. Post-encounter Return Rates and Relative Rank of Dietary Resources at North Creek Shelter.

\begin{tabular}{llcl}
\hline Category & \multicolumn{1}{c}{ Type } & Post-encounter Return Rate (kcal/hr) & Rank \\
\hline large mammal & deer, pronghorn, bighorn sheep & $15,725-31,450$ & A (high-rank) \\
small mammal & hares, cottontail rabbits & $8,983-15,400$ & B \\
tuber (USO) plants & tuber starch granules & $50-3,831$ & C \\
large seeds and nuts & pinyon seed coats, acorn nuts & $69-1,408$ & D \\
small seeds & Chenopodium and various small seeds & $92-1,307$ & E (low-rank) \\
\hline
\end{tabular}

Note: Return-rate values come from the published literature (e.g., Broughton et al. 2011; Couture et al. 1986; Diehl and Waters 2006; Gremillion 2004; Kelly 1995a; Rhode and Rhode 2015; Simms 1987; Smith and Martin 2001; Smith and McNees 2005; Ugan and Rosenthal 2016).

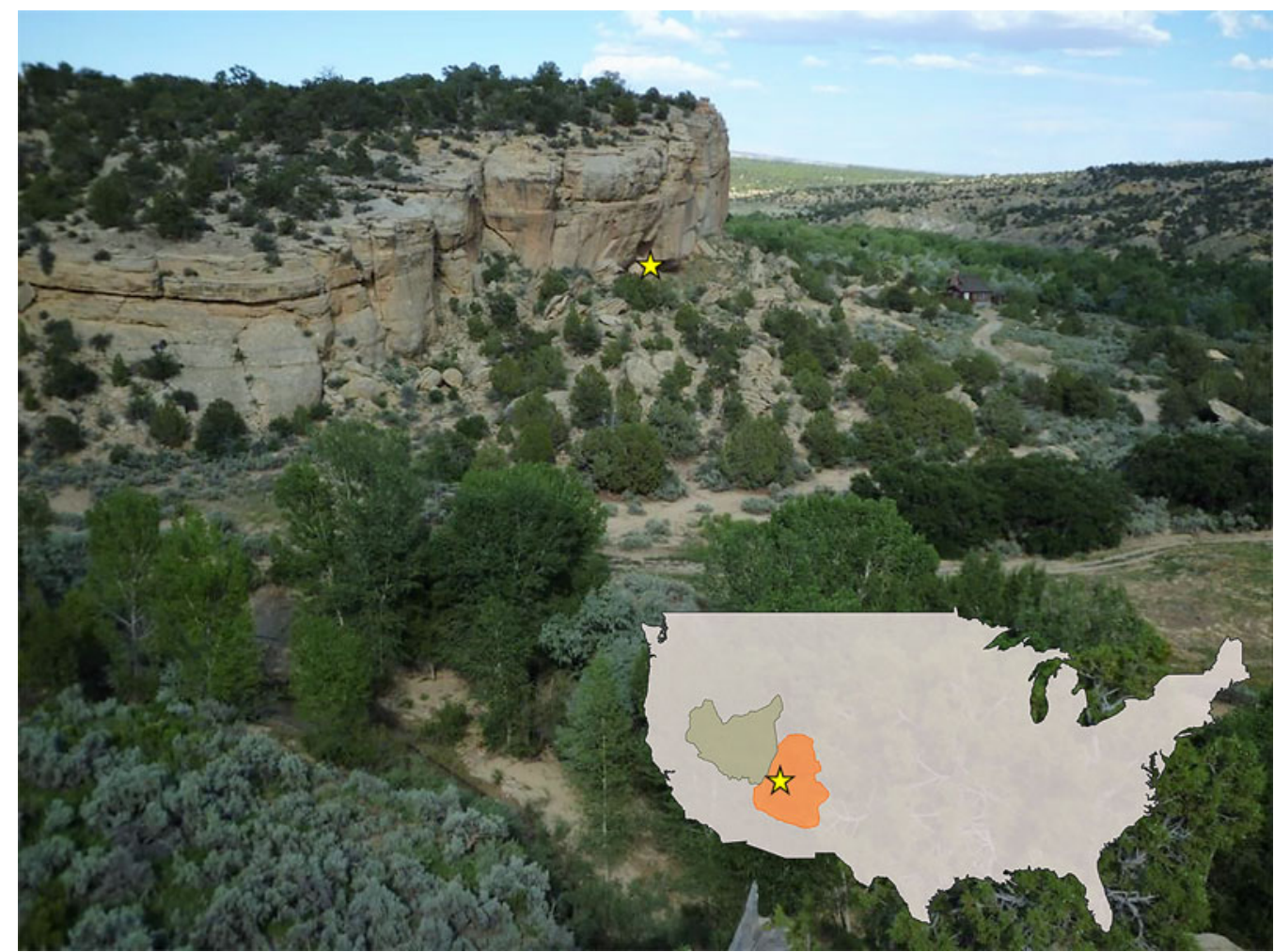

Figure 1. Location of North Creek Shelter (NCS) in Escalante on the Colorado Plateau in southern Utah (indicated by yellow star). Inset map shows the physiographic boundaries of the Great Basin (green) and Colorado Plateau (orange), and the yellow star is the approximate location of NCS.

climate change, an increase in leporids, small seeds, and ground stone tools should be positively correlated with warmer/drier climates. If the patterns do not conform, then alternative hypotheses must be examined.

\section{Site Setting and Stratigraphy}

NCS lies at the base $(1,900 \mathrm{~m}$ asl) of a southfacing sandstone cliff (Straight Cliffs Formation) overlooking Escalante Valley in southern Utah (Figure 1). The stratigraphic sequence is more than $4 \mathrm{~m}$ deep and contains many archaeological features - such as hearths and pits-as well as abundant stone tools, faunal assemblages, and botanical remains (Figure 2). The finds were recovered from cultural strata deposited between $11,300 \mathrm{cal}$ BP and $300 \mathrm{cal} \mathrm{BP}$, and they are defined as Paleoarchaic (Strata II, III, and IV; 11,300-10,200 cal BP), Early Archaic (Stratum 


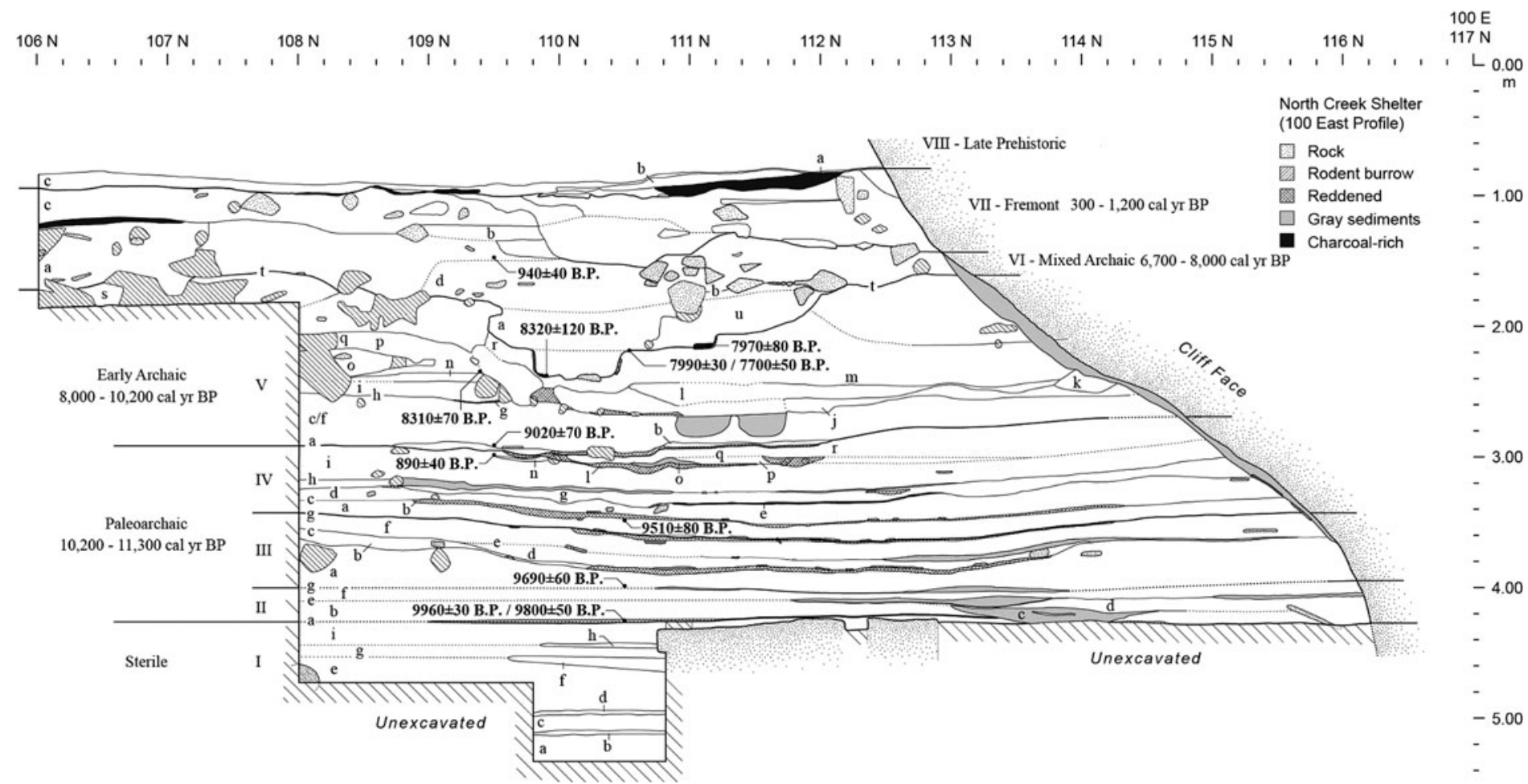

Figure 2. Stratigraphic profile of North Creek Shelter (adapted from Janetski et al. 2012). 
V; 10,200-8000 cal BP), Mixed Archaic (Stratum VI; 8000-6700 cal BP), Fremont (Stratum VII; 1200-300 cal BP), and Late Prehistoric (Stratum VIII; Figure 2). The strata were further subdivided into 68 substrata ( $\mathrm{Va}, \mathrm{Vb}, \mathrm{Vc}$, etc.) based on observable changes in the sediments, with some substrata interpreted as short-term living/use surfaces (see Janetski et al. 2012).

The assumption that these use surfaces represent human activity areas and therefore behavioral patterns over time comes from several criteria that Janetski and colleagues (2012) describe. For example, compacted and reddened sediments underlie several use surfaces throughout strata II-V. Artifacts as well as pit and hearth features lie flat and originate from the same surface, measuring just a few centimeters from the reddened sediments. The patterned distribution of artifacts and features (especially those from strata II-V) were sealed rapidly by depositional events during the early Holocene (see Janetski et al. 2012; Louderback et al. 2020). Furthermore, refitting efforts have found that matches occur within these discrete use surfaces.

For this study, dietary faunal and botanical remains are examined from cultural strata II-VI in order to capture the major climatic and vegetation changes (see Louderback et al. 2020) that might affect dietary choices during the early and middle Holocene and therefore reflect patterns in the diet breadth analyses. Stone tool abundances are also examined during this time period to determine if ground stone technology was developed at the same time as low-return resources were incorporated into the diet to maximize overall caloric returns. The chronological framework used by Louderback and colleagues (2020) is also used here. Radiocarbon ages for particular substrata (IIa, IIe, IIg, IIIa, IIIl, IIIe, Va, Vh, Vm, Vt, and VId) were calibrated using OxCal (Bronk-Ramsey and Lee 2013) and then averaged for substrata that did not have an associated radiocarbon age (Supplemental Figure 1; Supplemental Table 1).

\section{Methods}

\section{Faunal Dietary Patterns}

Faunal remains were recovered from a total of 53 substrata across strata II-VI. Descriptive summaries of the NCS mammalian fauna can be found in Janetski and colleagues (2012), Newbold (2009), and Johannson (2013). Previous evaluations of NCS faunal remains did not properly account for taphonomy, thereby potentially including noncultural taxa (e.g., carnivores and rodents) in analyses of diet breadth. This was avoided by using the annotated data records and segregating specimens into human and nonhuman accumulations based on burning and cut marks as cultural markers (see Louderback 2014:Appendices B and D). Additionally, relative abundance indexes had been previously calculated for cultural periods (e.g., Paleoarchaic and Early Archaic) rather than for individual substrata (e.g., Va, Vb, Vc, etc.), thereby blurring any quantitative changes that may have occurred. Consequently, relative abundances were recalculated for individual substrata rather than cultural periods. Applying a more rigorous assessment to faunal cultural markers and reexamining the NCS faunal remains by individual substrata resulted in a dietary dataset different from the ones previously published (Janetski et al. 2012; Newbold 2009). This new assessment excludes carnivores and rodents as dietary taxa (both of which lacked cultural markers) but keeps artiodactyls and leporids (Supplemental Table 2). Taxa were included using the lowest taxonomic category that could be assigned with confidence. Taxa represented by a single specimen in any given substratum were excluded in order to minimize the effects of an accidental movement of specimens across strata (Grayson 1991). The same means of counting taxa and/or specimens was applied consistently across all assemblages. The number of individual specimens (NISP) for dietary faunal remains are provided in Supplemental Table 2 and are archived in Dryad (https://datadryad.org/stash/dataset/doi:10.5061/ dryad.w9ghx3fq3).

Relative Abundance and Ubiquity. Relative abundance for each dietary faunal taxon was calculated using the following formula: ([ $\Sigma$ NISPtaxon $_{\mathrm{i}} / \Sigma$ NISPall faunal taxa] $\times 100$ ). It was used to measure changing abundances of a particular taxon over time, and it can inform about the importance of that taxon to past human diets. Relative abundance was calculated for both dietary faunal and botanical datasets. 
The ubiquity index (expressed as a percentage) describes the occurrence of a taxon based on number of features or stratigraphic units in which that resource is recovered: $\%$ of $\operatorname{taxon}_{i}=$ $(N$ of substrata with taxon $/ 2 N$ substrata $) \times 100$ (Popper 1988). Higher percentages indicate more pervasive use over time, which therefore has implications for the stability of resource availability as well as cultural importance. This was calculated for both faunal and botanical datasets.

\section{Botanical Dietary Patterns}

Macrobotanical remains (e.g., seeds, seed coats, fruits) were recovered by flotation analysis from hearth features $(n=156)$ excavated from 38 substrata spanning all cultural strata (II-VI) (Louderback 2014; Supplemental Table 2). Because these remains come from discrete hearth features (versus general cultural fill), they are considered human subsistence refuse if there is evidence of charring.

Identification of certain families is made possible by their diagnostic characteristics-such as the thick, ovoid, and large seed coats of Pinaceae or the angular, elongated, and small achenes of Asteraceae. Certain genera are also identified in this way; Chenopodium spp., for example, has lenticular, beaked, and rimmed seeds. C. berlandieri was isolated from all other Chenopodium spp. seeds because it has a distinctive reticulate pericarp and seed-coat patterning (Holmgren et al. 2012). Rhus sp. (sumac) seeds are ovoid with a radicle bulge (these specimens are distinctively striated, perhaps due to pericarp impression). In three cases, plant remains are identified to species: Atriplex confertifolia (shadscale) by its twowinged fruits, Achnatherum hymenoides (Indian ricegrass) by its distinctive flask-shaped achene, and Solanum jamesii (Four Corners potato) by its distinctive starch granules (Louderback and Pavlik 2017). Unidentified and indeterminate seeds and fruit are not included in the dietary analyses. The lowest possible taxonomic level was determined by using contemporary reference material from herbaria, seed reference collections, and plant specimens gathered at the study site itself. Local and regional floras are also used (e.g., Heil et al. 2013; Welsh et al. 2015). Nomenclature conforms to USDA GRIN (https://www. ars-grin.gov/).
Ninety-four ground stone tools spanning strata $\mathrm{V}$ and VI were analyzed for starch granules. The majority of tools were made from sandstone $(88 \%)$, with quartzite $(6 \%)$, volcanics $(5 \%)$, and granite $(1 \%)$ comprising the remainder. The weight of the tools varied from $4 \mathrm{~g}$ to approximately $13.5 \mathrm{~kg}$ (see Louderback [2014] for ground stone inventory and data). Starch granules were extracted following the protocols outlined in Louderback (2014) and Louderback et alia (2015), and granules were identified using the approached outlined in Louderback et alia (2017). Only starch granules with eccentric hila have been positively identified (Louderback and Pavlik 2017).

Because there is no way to determine an absolute count of starch granules, NISP is based on the number of ground stone tools that yielded identifiable granules in each substratum. For example, in substratum $\mathrm{Vt}$, three of the 20 ground stone tools bore granules assigned to Solanum jamesii. Therefore, the NISP value for $S$. jamesii in substratum Vt is three. The NISP for dietary botanical remains are provided in Supplemental Table 2 and are archived in Dryad (https:// datadryad.org/stash/dataset/doi:10.5061/dryad. w9ghx3fq3).

Relative Abundance and Ubiquity. Relative abundances and the ubiquity index were also calculated for dietary plant remains, using the same formulas mentioned above.

\section{Abundance Indexes}

The abundances of both higher- and lower-return resources are often used in archaeological studies to detect a broadening of the diet (e.g., Broughton 2002; Broughton et al. 2011; Codding et al. 2010). Abundance indexes express variability in foraging efficiency by calculating the ratio of higher-return prey relative to lowerreturn prey, where 1.0 indicates the sample is composed entirely of higher-return prey and 0.0 indicates the sample is composed entirely of lower-return prey (Bayham 1979; Broughton 2002; Codding et al. 2010; Grayson and Cannon 1999; Nagaoka 2001).

Artiodactyl Index. Bones of artiodactyls and leporids, the two most abundant dietary remains in the NCS faunal assemblage, were used to calculate an artiodactyl index: (NISP Artiodactyls $) /$ 
$\left(\mathrm{NISP}_{\text {Artiodactyls }}+\mathrm{NISP}_{\text {Leporids }}\right)$. Artiodactyls are typically ranked higher than leporids due to their large body size (e.g., Bayham 1979, Broughton et al. 2011), but recent research suggests that high risks (i.e., failed pursuits) are often not taken into account (Bird et al. 2009; Codding et al. 2010). Furthermore, leporids have been found to be low risk and a reliable resource, thereby increasing their overall return rates (Lupo et al. 2020; Morin et al. 2020). This study uses body size as the primary measure of prey rank and therefore supports the suggestion that artiodactyls are ranked higher than leporids.

High-Return Plant Index. A high-return plant index was calculated and used to detect a broadening of the diet (e.g., Weiss et al. 2004). This index is the ratio of higher-return plant-part remains (i.e., Pinaceae large seeds, Quercus nuts, $S$. jamesii tubers) relative to lower-return plant-part remains (i.e., small seeds), where 1.0 indicates the sample is entirely higher-return and 0.0 indicates the sample is entirely lower-return.

The return rates of geophytes from western North America can range widely from $50 \mathrm{kcal} /$ $\mathrm{hr}$ to up to $4,000 \mathrm{kcal} / \mathrm{hr}$ (Couture et al. 1986; Ugan and Rosenthal 2016). The tubers included in this study come from Solanum jamesii, a wild potato that grows across the Four Corners region (Kinder et al. 2017; Louderback and Pavlik 2017). A small population of $S$. jamesii is located approximately $150 \mathrm{~m}$ from NCS. Although return rate data are not yet available, this highly nutritious and productive perennial would have provided a reliable source of carbohydrates and minerals throughout the year. Handling costs would most likely have been minimal because its tubers are often found just below the litter layer in oak and conifer stands. Furthermore, $S$. jamesii tubers do not necessarily need to be cooked or roasted in order to be consumed. Various cooking and processing techniques for the tubers include drying, storing in a pit, and grinding into flour to make a bread (Castetter and Opler 1936). Given this information, S. jamesii tubers probably rank highly among geophytes with respect to post-encounter return rates.

Chipped Stone Tool Index. A chipped stone tool index was applied to determine when ground stone tools were employed at NCS. It is the ratio of chipped stone tools (i.e., projectile points) relative to ground stone tools (i.e., manos and metates), where 1.0 indicates the sample is composed entirely of chipped stone tools and 0.0 indicates the sample is composed entirely of ground stone tools. The NISP for chipped and ground stone tools are provided in Supplemental Table 2 and are archived in Dryad (https://datadryad.org/ stash/dataset/doi:10.5061/dryad.w9ghx3fq3).

Climate Index. A climate index is calculated using the ratio between conifer and Amaranthaceae pollen analyzed from NCS sediments (Supplemental Table 2 and Dryad https://datadryad. org/stash/dataset/doi:10.5061/dryad.w9ghx3fq3), where 1.0 indicates the sample is composed entirely of conifer pollen (Abies, Picea, Pseudotsuga, Pinus, indicating cool conditions) and 0.0 indicates the sample is composed entirely of Amaranthaceae pollen (arid conditions; Louderback et al. 2020). Other climate indexes could have been used in this study, including the cooladapted/warm-adapted conifer ratio based on NCS plant macrofossils (Louderback et al. 2020) or regional pollen and plant macrofossil records, such as Anderson and colleagues (1999), Betancourt (1984), Withers and Mead (1993), or Coats and colleagues (2008). All of these regional records corroborate the Holocene vegetation shifts and increasing aridity observed at NCS.

Temporal Sequencing. The artiodactyl and high-return plant indexes along with the chipped stone tool and climate indexes are plotted through time. A generalized linear model (GLM) of the binomial family (with quasi-likelihood estimation) and a "logit" link function was applied (McCullagh and Nelder 1989) and plotted using the $\mathrm{R}$ Programming Language ( $\mathrm{R}$ Core Team 2019). The $R$ code is published at Zenodo (https://doi.org/10.5281/zenodo.5123350). The quasibinomial GLM applies to proportional data and is therefore used for all indexes in this study.

\section{Effects of Climate on Dietary Choices}

Artiodactyl, chipped stone tool, and high-return plant indexes were regressed against the climate index to determine the effects of climate on dietary choices. If diet breadth and/or a shift to more expensive technology and low-return resources 
are coincident with climate change, then negative relationships should be apparent. A quasibinomial GLM with a "logit" link function was applied to each plot using the R Programming Language ( $\mathrm{R}$ Core Team 2019). The $\mathrm{R}$ code is published at Zenodo (https://doi.org/10.5281/ zenodo.5123350).

\section{Results}

\section{Faunal Dietary Patterns}

NISP and NTAXA for dietary faunal remains are presented in Supplemental Table 2. Six different dietary taxa were identified in the NCS faunal remains. High-ranked fauna include Antilocapra americana (pronghorn), Cervus elaphus (elk), Odocoileus hemionus (mule deer), and Ovis canadensis (bighorn sheep). Low-ranked fauna include Lepus sp. (hares) and Sylvilagus sp. (cottontail rabbits).

Relative Abundance and Ubiquity. Abundances of dietary faunal remains vary through time, ranging from one to over 350 bones in a single substratum. The lowest abundances occur throughout strata IV $(10,500-10,000 \mathrm{cal}$ BP) and VI ( 7400-6700 cal BP). Higher abundances occur in strata II, III $(11,300-10,500 \mathrm{cal}$ BP), and V (9800-7600 cal BP). Deer make up $76 \%$ of the assemblage, regardless of when they were deposited, making this dietary resource both abundant and ubiquitous (87\%; Figure 3). In contrast, Sylvilagus, Lepus, and Ovis bones are ubiquitous $(85 \%, 66 \%$, and $47 \%$, respectively) but not very abundant $(16 \%, 4 \%$, and $4 \%$, respectively). This suggests constant but low-level use. Other dietary faunal taxa (Antilocapra and Cervus) are neither abundant (totaling less than $0.7 \%$ ) nor ubiquitous (11\% and $8 \%$, respectively), suggesting opportunistic or ephemeral use.

\section{Botanical Dietary Patterns}

A total of 21 types of dietary plant taxa were recovered from 156 hearth features at NCS. This includes 17 families, 12 genera, and three that were identified to species level. Several potentially important dietary items are absent or rare, such as roots, tubers, berries, and other plants that lack dense, easily preserved parts. Some of these, such as tubers, may not show up in the macrobotanical record simply for reasons of differential preservation, but they do show up in the form of starch granules preserved in the cracks and crevices of ground stone tools. One such tuber, Solanum jamesii, was identified and included in dietary analyses for this study (see Louderback and Pavlik 2017).
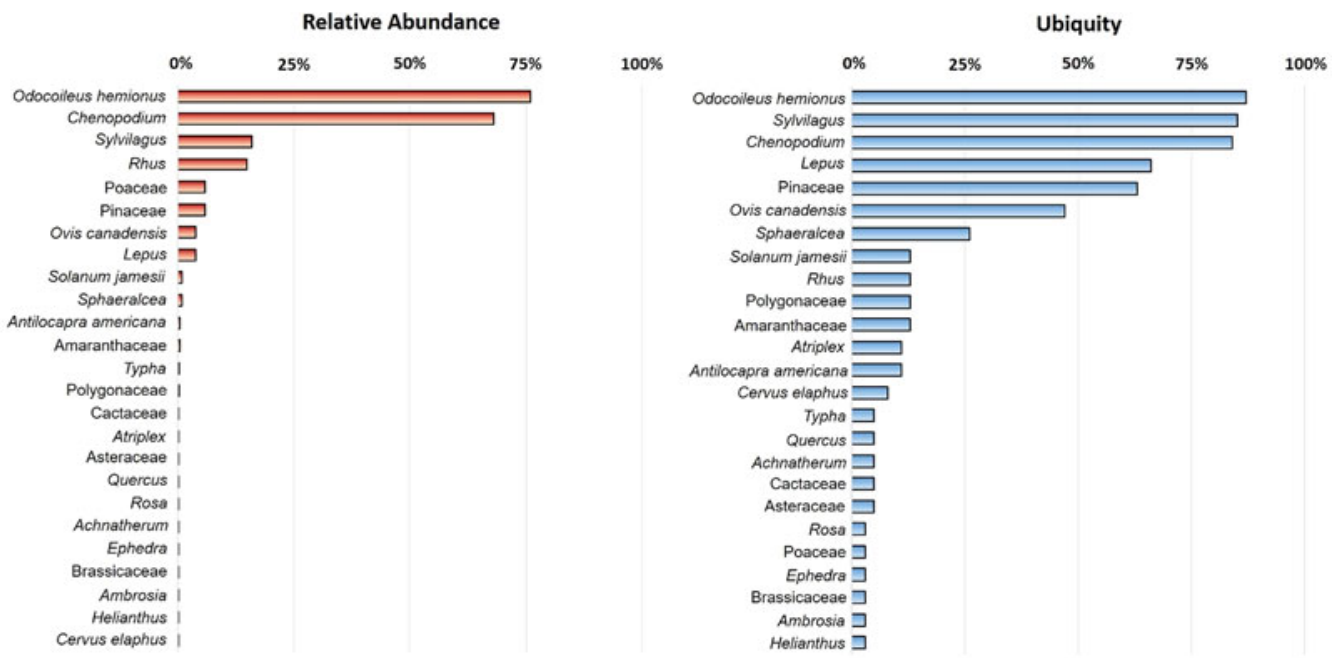

Figure 3. Relative abundance and ubiquity (frequency of occurrence) for dietary faunal and botanical datasets at NCS. Relative abundances for faunal and botanical taxa were calculated separately $\left(\Sigma N_{I S P}\right.$ faunal $=\mathbf{2 , 8 7 1}$ and $\Sigma$ NISP $_{\text {botanical }}=$ 1,568). Ubiquity was also calculated separately $\left(\Sigma\right.$ substrata $_{\text {faunal }}=53, \Sigma$ substrata $\left._{\text {botanical }}=38\right)$. 
Relative Abundance and Ubiquity Index. Abundances of dietary macrobotanical remains fluctuate through time, ranging from one to more than 280 seeds, seed coats, fruits, and fragments in a single substratum. The lowest abundances occur throughout strata II and IV (11,300-10,000 cal BP). These plant materials tend to be Pinaceae seeds. Higher abundances of dietary plant remains occur in substrata IIIc and IIIe $(10,800-10,600$ cal BP) as well as throughout strata V and VI $(10,000-6700 \mathrm{cal}$ BP). Remains of Chenopodium seeds and fruits are dominant in these deposits, although they are matched in abundance by Rhus sp. seeds in substrata Vh and Vi (9300-9100 cal BP). Overall, there is a progressive increase in dietary plant remains after substratum $\mathrm{Va}(\sim 10,000 \mathrm{cal} \mathrm{BP})$.

Chenopodium seeds make up $68 \%$ of the assemblage, regardless of when they were deposited, making this dietary resource both abundant and ubiquitous (84\%; Figure 3). In contrast, Pinaceae seed coats and Sphaeralcea sp. seeds are ubiquitous (63\% and $26 \%$, respectively) but not very abundant (5\% and $1 \%$, respectively). This suggests constant but low-level use. Rhus sp. seeds, which are the second most abundant plant remains $(15 \%)$, occur in only $13 \%$ of all strata.
Most other dietary plant taxa are neither abundant nor ubiquitous, suggesting opportunistic or ephemeral use. It is noteworthy that members of Chenopodiaceae and Amaranthaceae have a total ubiquity index of $97 \%$, therefore dominating the diet through a considerable period of time.

\section{Abundance Indexes}

Artiodactyl Index. Artiodactyl index values (Figure 4) are lowest throughout stratum IV $(10,500-10,000 \mathrm{cal}$ BP) as well as in substrata Vt, VIa, and VId ( 8100-7000 cal BP). Values are highest in strata II and III $(11,300-10,600$ cal BP) as well as in substrata Vf-Vs (94008130 cal BP). Overall, the NCS assemblage is dominated by artiodactyls that, relative to leporids, do not decline significantly over time ( $p=$ 0.78; Supplemental Table 3).

High-Return Plant Index. High-return plant index values (Figure 4) are highest in substrata IIa, IIc, IIe, IIIg, and $\mathrm{Vb}$, which date from 11,300 to 9800 cal BP and then significantly decline $(p<0.01)$ as small seeds increase in abundance during the early and middle Holocene ( 10,000-7000 cal BP; Supplemental Table 3). It is important to note, however, that tubers of $S$. jamesii were also collected between 8100
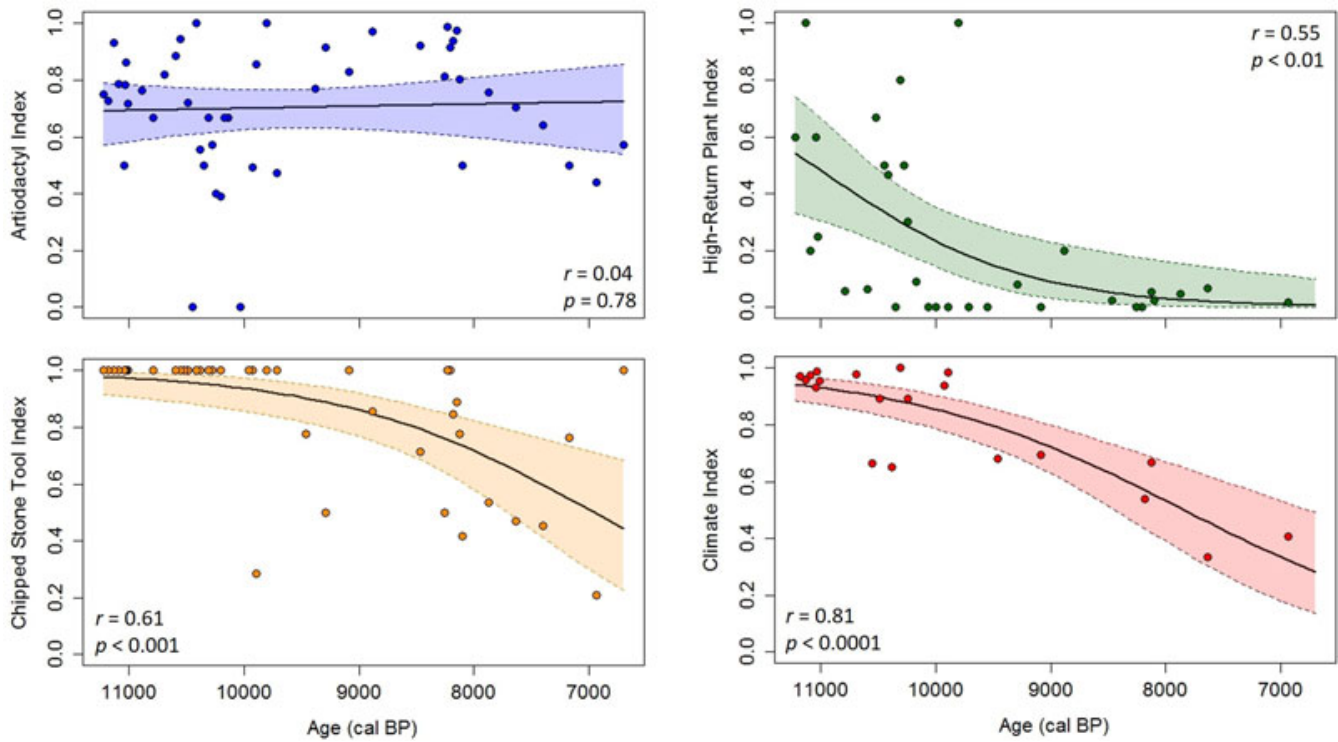

Figure 4. Artiodactyl, high-return plant, chipped stone tool, and climate indexes plotted against time using datasets from NCS. Dashed lines represent $95 \%$ confidence intervals around the GLMs (quasibinomial with a "logit" link function). Correlation coefficient $(r)$ and probabilities $(P)$ of the GLM are indicated. 
and 7600 cal BP (substrata Vt, Vu, VIa) and processed on ground stone tools.

Chipped Stone Tool Index. Chipped stone tool index values (Figure 4) are highest in strata II, III, and IV, which date from 11,300 to $10,000 \mathrm{cal}$ BP. Ground stone tools first appear in substratum Va (9900 cal BP) and steadily increase in abundance $(p<0.001)$ until 6700 cal BP (Supplemental Table 3). This increase in ground stone tool use correlates with the increased abundance of all small seeds $(r=$ $+0.60, p<0.0001$; see Louderback 2014).

Climate Index. Climate index values (Figure 4) are highest in strata II, III, IV, and Va (11,300-9900 cal BP), indicating cool/ moist conditions. But they begin to decline significantly in substrata Vf, Vi, Vq, Vs, VIa, and Vid (9500-6700 cal BP) when conditions become more arid $(p<0.0001$; Louderback et al. 2020; Supplemental Table 3).

\section{Effects of Climate on Dietary Choices}

There is no significant relationship between the abundance of higher-ranked faunal resources and climate $(p=0.87)$, but negative relationships, albeit nonsignificant, exist between the chipped stone tools and climate $(p=0.12)$ as well as the high-return plant resources and climate ( $p=0.14$; Figure 5; Supplemental Table 3). In other words, as climate gets warmer, the abundances of ground stone tools and small seeds increase.

\section{Discussion}

The diet breadth model (Stephens and Krebs 1986) predicts that decreasing encounters with high-ranked resources should result in increasing use of lower-ranked resources, therefore reflecting adjustments in human foraging behavior. At North Creek Shelter, this prediction appears valid with respect to botanical resources because high-ranked plants such as pine nuts and acorns drop out of the diet after $9800 \mathrm{cal}$ BP and are replaced with low-ranked, small seeds. The prediction is not met, however, with respect to the faunal resources where high-ranked artiodactyls are consistently abundant in the diet throughout the Holocene and are not replaced with lowranked leporids for any sustained amount of time.
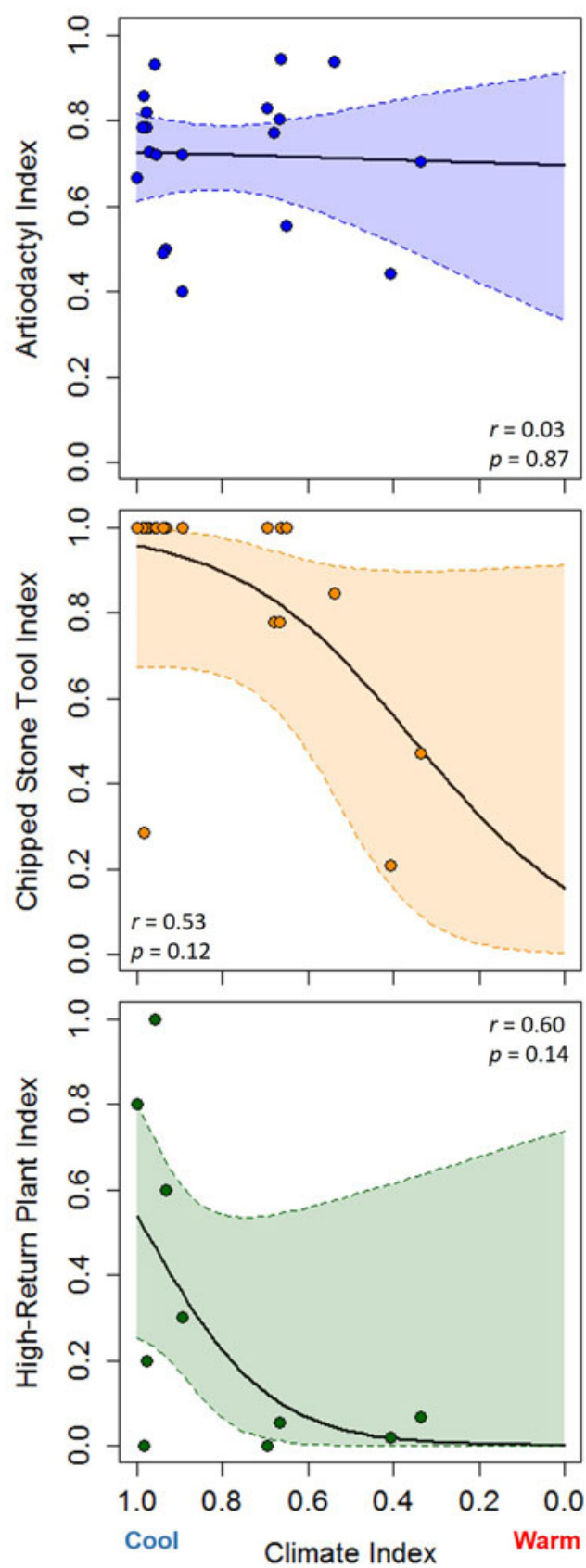

Figure 5. Artiodactyl, chipped stone tool, and high-return plant indexes plotted against the climate index to determine the effects of climate on dietary choices. Dashed lines represent $95 \%$ confidence intervals around the GLMs (quasibinomial with a "logit" link function). Correlation coefficient $(r)$ and probabilities $(P)$ of the GLM are indicated. 
In arid regions on a global basis, increasing aridity and resultant changes in vegetation composition are offered as the ecosystem drivers of changes in dietary patterns (e.g., Edwards and O'Connell 1995; O'Connell and Hawkes 1981, 1984; O'Connell et al. 1982; Rhode and Louderback 2007; Rhode et al. 2006). Increasing aridity at NCS began by 10,200 cal BP and progressed significantly by $9300 \mathrm{cal} \mathrm{BP}$, which was indicated by a shift in vegetation from a mixed conifer forest of cool-adapted species to a semiarid woodland and shrub mosaic (Louderback et al. 2020). This increased aridity coincides with greater use of small seeds and ground stone tools but not with corresponding increases in leporid abundances.

The NCS dataset contains fundamental lines of evidence encompassing diet and climate over time from a single site, which therefore allows for a true test of predictions of the diet breadth model. Other sites in the arid West that contain faunal, botanical, and stone tool datasets (e.g., Danger Cave, Bonneville Estates Rockshelter, Cowboy Cave, Sudden Shelter) were not analyzed specifically to test diet breadth predictions. Instead, they examined for differences between Paleoarchaic and Archaic subsistence patterns (Geib and Jolie 2018; Madsen 2007; Rhode and Louderback 2007; Rhode et al. 2006). In examining these patterns, generalizations regarding diet breadth between Paleoarchaic and Archaic foragers were not quantitatively tested and were primarily based on a single line of evidence (e.g., ground stone tool abundance) rather than multiple indicators. In addition, some of those lines of evidence come from very different places and probably from different groups of people experiencing very different resource landscapes across time.

Two major questions arise from the current study:

(1) Why did high-ranked faunal resources not decline in the deposits of NCS when there was clear development of aridity and changes in regional vegetation? Faunal records from Great Basin archaeological sites during the late Pleistocene / early Holocene tend to be characterized by a diverse array of smaller, low-ranked prey such as birds, lagomorphs, fish, and insects (Grayson 1988; Hockett 2015; Hockett et al. 2017; Pinson 2007). Artiodactyls do not become abundant in those deposits until the middle Holocene (e.g., Hockett 2015; Pinson 2007), and they increase even more during the late Holocene (Broughton et al. 2008, 2011; Hockett 2015). At NCS, artiodactyls are as abundant during the early Holocene at 11,000 cal BP (substratum IIf, $\mathrm{NISP}=181)$ as they are during the middle Holocene at 7900 cal BP (substratum Vu, NISP = 136), although abundances vary throughout these time periods. Perhaps local depletion of deer populations was regularly mitigated by immigration from distant sources. Unlike the Great Basin, the landscapes of the northern Colorado Plateau consist of nearly continuous and large areas of upland that may have provided corridors for constantly reestablishing herds in the vicinity of NCS, regardless of climate-driven vegetation change. In southern Utah, deer are now ubiquitous, occupying and moving between essentially all vegetation zones, from subalpine forests to desert scrub (Durrant 1952). That they would be present during the climatic shift to aridity between the early and middle Holocene is, therefore, not surprising. This has been suggested for other faunal patterns in the region (e.g., Sudden Shelter; Broughton et al. 2011; Byers and Broughton 2004).

Another hypothesis for large game hunting throughout the Holocene is based on costly signaling and "showing off" rather than foraging efficiency (Hildebrandt and McGuire 2002). The show-off hypothesis suggests that male hunters gain higher fitness by choosing "risky" resources that can be shared widely. Although this might explain the consistent or increased abundance of large game resources in archaeological sites, it has been refuted by many researchers on the basis of empirical, theoretical, and methodological evidence (Broughton and Bayham 2003; Byers and Broughton 2004; Codding and Jones 2007; Fisher 2015; Grimstead 2010; Gurven and Hill 2009). More importantly, it has also been suggested that the 
show-off hypothesis may not result in the highest fitness-related benefits (Hawkes 1990, 1991).

(2) What is the driver for broadening of diets at NCS if not a decline in high-ranked faunal resources? The patterns observed from the NCS faunal and botanical datasets may reflect different foraging strategies between men and women, which would explain why low-ranked plant resources became increasingly abundant in the diet without a corresponding decrease in the abundance of high-ranked artiodactyls. Gender-specific foraging in the archaeological record is something that has been explored before, and in the case of the Carson Desert in $\mathrm{Ne}$ vada, it has been modeled and tested using archaeological data (e.g., Elston and Zeanah 2002; Kelly 1995b, 1997; Larsen and Hutchinson 1999; Larsen and Kelly 1995; Larsen et al. 1995; Rhode 2003; Schoeninger 1995, 1999; Zeanah 2004). The prevailing consensus from those studies suggests that men and women had different goals: women stayed near home base to forage in productive lowland patches, whereas men forayed into the uplands for large-game resources (Zeanah 2004). More recent research (Codding et al. 2010; Elston et al. 2014) elaborates on those findings by suggesting that some undefined level of variability in acquiring large game would lead to women simultaneously foraging for more reliable but lower-ranked resources. Likewise, the lack of ground stone tools in archaeological sites prior to $10,000 \mathrm{cal} \mathrm{BP}$ (Grayson 2011; Madsen 2007) suggests that gender-specific foraging patterns were more "convergent" (sensu Codding et al. 2010; Elston et al. 2014) because foragers would not have stayed in one location long enough for women to invest in that technology. Sometime after $10,000 \mathrm{cal}$ $\mathrm{BP}$, foraging patterns of men and women would have "diverged" if acquiring game was more unpredictable and foragers were staying in one place for longer periods of time.

These predictions regarding genderspecific foraging patterns are drawn from ethnographic studies of modern foragers. For example, gender and age differences in foraging patterns have been investigated among the Aché and the Hadza. The Aché are indigenous hunter-gatherers who live in the tropical forests of eastern Paraguay, and the Hadza are traditional foragers who inhabit the arid savannah woodland of northern Tanzania. Based on ethnographic studies, both of these groups defy diet breadth expectations that foragers will maximize their mean energetic rates because reproductive fitness costs and benefits may be different for men and women (O'Connell et al. 1999). Aché men and women, for example, have different foraging strategies based on their goals (Codding et al. 2011; Hawkes 1990; Hawkes et al. 1991; Hill et al. 1987; Hurtado et al. 1985). Aché women tend to be risk averse due to family provisioning. Consequently, they forage in more reliable resource patches, accumulating more low-return resources, heavily investing in plant-processing tools, and keeping the food for themselves and their children (Hawkes 1991). Aché men pursue fluctuating but highly mobile large-bodied animals, and when they are successful, their prey is shared widely (Hawkes 1991). Ethnographic studies also indicate that women's foraging strategies are good indicators of diet breadth due to risk-averse foraging goals as well as climate change, whereas men's are not (Hurtado et al. 1985; O'Connell and Hawkes 1984; O'Connell et al. 1999). In the case of the Hadza foragers, children are able to collect their own plant resources (i.e., fruits) during the wet season. But with increases in aridity and seasonality, those plant resources may not be available for children. Therefore, Hadza women provision with resources that tend to have high handling costs (such as small seeds and tubers; Hawkes et al. 1997; O'Connell et al. 1999; Wood et al. 2021). This is exactly what may be registered with the NCS record, and it is probably the best explanation for the differing patterns observed in the faunal and botanical assemblages at NCS. 
At NCS, complementary faunal and botanical assemblages provide an opportunity to identify gender-specific foraging patterns across a long arc of time and environmental change. The current study posits that prior to $10,500 \mathrm{cal} \mathrm{BP}$, variability in acquiring artiodactyls was low (coefficient of variation [CV] for artiodactyl index strata $\mathrm{II}=0.18$ and $\mathrm{III}=0.13$ ) compared to after (CV for strata $\mathrm{IV}=0.54, \mathrm{~V}=0.19$ and $\mathrm{VI}=0.19$ ). This means that when NCS was surrounded in cool-adapted conifers, women were not staying in one place collecting small seeds and using ground stone tools to process them. Instead, they may have been participating in hunts and/or opportunistically collecting highreturn plant food resources, such as large-seeded pine nuts. Gender-specific foraging patterns at NCS prior to $10,500 \mathrm{cal}$ BP therefore seem to align with convergent patterns of labor division (Codding et al. 2010; Elston et al. 2014). After 10,500 cal BP, however, when conditions were becoming more arid, women apparently began collecting small seeds from various shrubby and herbaceous plants, as well as $S$. jamesii tubers (Louderback and Pavlik 2017) persisting beneath canopies and along watercourses. Ground stone tools were used to process those plant parts, thereby maximizing the overall caloric returns. Men, on the other hand, were consistently hunting artiodactyls, even though there was considerable variability in this record.

\section{Conclusions}

Although gender plays an important role in human foraging strategies (Hawkes and O'Connell 1992; Jochim 1988), it is rarely addressed during archaeological studies, especially when considering diet breadth variations through time. The NCS archaeological assemblage suggests that women and men had different foraging patterns in response to environmental change. This could be tested more widely by applying optimal foraging models to many archaeological sites in the Great Basin and on the Colorado Plateau that also have complementary faunal, botanical, stone tool, and environmental datasets.

Acknowledgments. This research was supported by National Science Foundation (NSF) Doctoral Dissertation Improvement Grant (Award BCS-1262835), awarded to the author in 2012. The author would like to thank friends and colleagues who provided advice and constructive criticisms on early versions of the manuscript, including Jack Broughton, Brian Codding, Tyler Faith, Don Grayson, Kristen Hawkes, Joel Janetski, Jim O'Connell, David Rhode, and the University of Utah Archaeology Center Lab group. The author is also grateful to Bruce Pavlik for editing the manuscript and offering additional insights, as well as to Debra Martin and three anonymous reviewers. Thanks to Phoebe McNeally (Digit Lab, University of Utah) for making the map, Blake Vernon for providing R help, and Fanny Blauer for translating the abstract into Spanish. This research would not be possible without Joel Janetski's impeccable excavation of North Creek Shelter and his support throughout the author's dissertation research. And finally, thanks to the Rex family-especially Joette-Marie Rex - for hospitality, friendship, and continued access to North Creek Shelter.

Data Availability Statement. Data from this project are available and archived at Dryad: https://datadryad.org/stash/ dataset/doi:10.5061/dryad.w9ghx3fq3. R code is published at Zenodo: https://doi.org/10.5281/zenodo.5123350.

Supplemental Material. For supplemental material accompanying this article, visit https://doi.org/10.1017/aaq.2021.122.

Supplemental Figure 1. Schematic diagram showing North Creek Shelter (NCS) radiocarbon age probability distributions by substratum. Calibrated ages are plotted as filled curves connected by a dotted line. Hatched curves are outlying or old wood ages (not used in this study). Probability distributions were calibrated and imported from OxCal (Bronk-Ramsey and Lee 2013). (Figure published in Louderback et al. 2020.)

Supplemental Table 1. Radiocarbon Dates from North Creek Shelter.

Supplemental Table 2. Number of Individual Specimens (NISP) of Dietary Faunal and Botanical Remains, Chipped Stone and Ground Stone Tools, and Pollen from Substrata at North Creek Shelter.

Supplemental Table 3. Summary of Model Results Including the Estimate, Standard Error, $T$-Value and $P$-Value for the Parametric Terms.

\section{References Cited}

Anderson, R. Scott, Jim Hasbargen, Peter A. Koehler, and Eric J. Feiler

1999 Late Wisconsin and Holocene Subalpine Forests of the Markagunt Plateau of Utah, Southwestern Colorado, U.S.A. Arctic, Anarctic, and Alpine Research 31:366378.

Bayham, Frank E.

1979 Factors Influencing the Archaic Pattern of Animal Utilization. Kiva 44:219-235.

Betancourt, Julio L.

1984 Late Quaternary Plant Zonation and Climate in Southeastern Utah. Great Basin Naturalist 44:1-35.

Bird, Douglas W., Rebecca Bliege Bird, and Brian F. Codding

2009 In Pursuit of Mobile Prey: Martu Hunting Strategies and Archaeofaunal Interpretation. American Antiquity 74:3-29. 
Bronk-Ramsey, Christopher, and Sharen Lee

2013 Recent and Planned Developments of the Program OxCal. Radiocarbon 55:120-130.

Broughton, Jack M.

2002 Prey Spatial Structure and Behavior Affect Archaeological Tests of Optimal Foraging Models: Examples from the Emeryville Shellmound Vertebrate Fauna. World Archaeology 34:60-83. DOI:10.1080/00438240 220134269.

Broughton, Jack M., and Frank E. Bayham

2003 Showing Off, Foraging Models, and the Ascendance of Large-Game Hunting in the California Middle Archaic. American Antiquity 68:783-789.

Broughton, Jack M., David A. Byers, Reid A. Bryson, William Eckerle, and David B. Madsen

2008 Did Climatic Seasonality Control Late Quaternary Artiodactyl Densities in Western North America? Quaternary Science Reviews 27:1916-1937. DOI:10.1016/j. quascirev.2008.07.005.

Broughton, Jack M., Michael D. Cannon, Frank E. Bayham, and David A. Byers

2011 Prey Body Size and Ranking in Zooarchaeology: Theory, Empirical Evidence, and Applications from the Northern Great Basin. American Antiquity 76:403428 .

Broughton, Jack M., and Donald K. Grayson

1993 Diet Breadth, Adaptive Change, and the White Mountain Faunas. Journal of Archaeological Science 20:331-336. DOI:10.1006/jasc.1993.1020.

Byers, David A., and Jack M. Broughton

2004 Holocene Environmental Change, Artiodactyl Abundances, and Human Hunting Strategies in the Great Basin. American Antiquity 69:235-255. DOI:10. 2307/4128418.

Castetter, Edward F., and Morris E. Opler

1936 Ethnobiological Studies in the American Southwest III: The Ethnobiology of the Chiricahua and Mescalero Apache. University of New Mexico Bulletin 4(5):1-63.

Coats, Larry L., Kenneth L. Cole, and Jim I. Mead

2008 50,000 Years of Vegetation and Climate History on the Colorado Plateau, Utah and Arizona, USA. Quaternary Research 70:322-338.

Codding, Brian F., Douglas W. Bird, and Rebecca Bliege Bird

2010 Interpreting Abundance Indices: Some Zooarchaeological Implications of Martu Foraging. Journal of Archaeological Science 37:3200-3210. DOI:10.1016/j. jas.2010.07.020.

Codding, Brian F., Rebecca Bliege Bird, and Douglas W. Bird

2011 Provisioning Offspring and Others: Risk-Energy Trade-Offs and Gender Differences in Hunter-Gatherer Foraging Strategies. Proceedings of the Royal Society $B$ 278:2502-2509. DOI:10.1098/rspb.2010.2403.

Codding, Brian F., and Terry L. Jones

2007 Man the Showoff? Or the Ascendance of a Just-So-Story: A Comment on Recent Applications of Costly Signaling Theory in American Archaeology. American Antiquity 72:349-357. DOI:10.2307/ 40035818.

Couture, Marilyn D., Mary F. Ricks, and Lucile Housley 1986 Foraging Behavior of a Contemporary Northern Great Basin Population. Journal of California and Great Basin Anthropology 8:150-160.

Diehl, Michael W., and Jennifer A. Waters

2006 Aspects of Optimization and Risk during the Early Agricultural Period in Southeastern Arizona. In
Behavioral Ecology and the Transition to Agriculture, edited by Douglas J. Kennett and Bruce Winterhalder, pp. 63-86. University of California Press, Berkeley.

Durrant, Stephan D.

1952 Mammals of Utah: Taxonomy and Distribution. Museum of Natural History. University of Kansas, Lawrence.

Edwards, Douglas A., and James F. O'Connell

1995 Broad Spectrum Diets in Arid Australia. Antiquity 69:769-783. DOI:10.1017/S0003598X00082326.

Elston, Robert G., and David W. Zeanah

2002 Thinking Outside the Box: A New Perspective on Diet Breadth and Sexual Division of Labor in the Prearchaic Great Basin. World Archaeology 34:103-130. DOI:10.1080/00438240220134287.

Elston, Robert G., David W. Zeanah, and Brian F. Codding

2014 Living Outside the Box: An Updated Perspective on Diet Breadth and Sexual Division of Labor in the Prearchaic Great Basin. Quaternary International 352:200-211. DOI:10.1016/j.quaint.2014.09.064.

Fisher, Jacob L.

2015 Faunal Quantification and the Ascendance of Hunting Debate: Reevaluation of the Data from Southeastern California. American Antiquity 80:767-775. DOI:10. 7183/0002-7316.80.4.767.

Flannery, Kent V.

1969 Origins and Ecological Effects of Early Domestication in Iran and the Near East. In The Domestication and Exploitation of Plants and Animals, edited by Peter J. Ucko and G. W. Dimbleby, pp. 73-100. Duckworth, London.

Geib, Phil R., and Edward A. Jolie

2018 The Rise of Broad Spectrum Foraging on the Colorado Plateau during the Early Holocene. In The Archaic Southwest, edited by Bradley J. Vierra, pp. 189-214. University of Utah Press, Salt Lake City.

Grayson, Donald K.

1988 Danger Cave, Last Supper Cave, and Hanging Rock Shelter: The Faunas. Anthropological Papers 66. American Museum of Natural History, New York.

1991 Alpine Faunas from the White Mountains, California: Adaptive Change in the Late Prehistoric Great Basin. Journal of Archaeological Science 18:483-506.

2000 Mammalian Responses to Middle Holocene Climatic Change in the Great Basin of the Western United States. Journal of Biogeography 27:181-192. DOI:10. 1046/j.1365-2699.2000.00383.x.

2011 The Great Basin: A Natural Prehistory. University of California Press, Berkeley.

Grayson, Donald K., and Michael Cannon

1999 Human Paleoecology and Foraging Theory in the Great Basin. In Models for the Millennium: Great Basin Anthropology Today, edited by Charlotte Beck, pp. 141-151. University of Utah Press, Salt Lake City.

Gremillion, Kristen J.

2004 Seed Processing and the Origins of Food Production in Eastern North America. American Antiquity 69:215233.

Grimstead, Deanna N.

2010 Ethnographic and Modeled Costs of Long-Distance, Big-Game Hunting. American Antiquity 75:61-80. DOI:10.7183/0002-7316.75.1.61.

Gurven, Michael, and Kim Hill

2009 Why Do Men Hunt? A Reevaluation of "Man the Hunter" and Sexual Division of Labor. Current Anthropology 50:51-74. 
Hawkes, Kristen

1990 Why Do Men Hunt? Some Benefits for Risky Strategies. In Risk and Uncertainty in Tribal and Peasant Economies, edited by Elizabeth Cashdan, pp. 145166. Westview Press, Boulder, Colorado.

1991 Showing Off: Tests of an Hypothesis about Men's Foraging Goals. Ethnology and Sociobiology 12:29-54.

Hawkes, Kristen, and James F. O'Connell

1992 On Optimality Models and Subsistence Transitions. Current Anthropology 33:63-66.

Hawkes, Kristen, James F. O'Connell, and Nick G. Blurton-Jones

1991 Hunting Income Patterns among the Hadza: Big Game, Common Goods, Foraging Goals, and the Evolution of the Human Diet. Philosophical Transactions of the Royal Society B 334:243-251. DOI:10.1098/rstb. 1991.0113.

1997 Hadza Women's Time Allocation, Offspring Provisioning, and the Evolution of Long Menopausal Life Spans. Current Anthropology 38:551-577

Heil, Kenneth D., Steve L. O'Kane Jr., Linda Mary Reeves, and Arnold Clifford

2013 Flora of the Four Corners Region: Vascular Plants of the San Juan River Drainage: Arizona, Colorado, New Mexico, and Utah. Missouri Botanical Garden Press, St. Louis.

Hildebrandt, William R., and Kelly R. McGuire

2002 The Ascendance of Hunting during the California Middle Archaic: An Evolutionary Perspective. American Antiquity 67:231-256.

Hill, Kim, Hillard Kaplan, Kristen Hawkes, and A. Magdalena Hurtado

1987 Foraging Decisions among Aché Hunter-Gatherers: New Data and Implications for Optimal Foraging Models. Ethology and Sociobiology 8:1-36.

Hockett, Bryan

2015 The Zooarchaeology of Bonneville Estates Rockshelter: 13,000 Years of Great Basin Hunting Strategies. Journal of Archaeological Sciences: Reports 2:291301. DOI:10.1016/j.jasrep.2015.02.011.

Hockett, Bryan, Martin E. Adams, Patrick M. Lubinski, Virginia L. Butler, and Dennis L. Jenkins

2017 Late Pleistocene Subsistence in the Great Basin: Younger Dryas-Aged Faunal Remains from the Botanical Lens, Paisley Cave 2, Oregon. Journal of Archaeological Science: Reports 13:565-576. DOI:10.1016/j. jasrep.2017.05.003.

Holmgren, Noel H., Patricia K. Holmgren, and James L. Reveal

2012 Intermountain Flora: Vascular Plants of the Intermountain West, U.S.A, Vol. 3, Part A: Subclasses Magnoliidae-Caryophyllidae. New York Botanic Garden Press, New York.

Hurtado, Ana M., Kristen Hawkes, Kim Hill, and Hillard Kaplan

1985 Female Subsistence Strategies among Ache Hunter-Gatherers of Eastern Paraguay. Human Ecology 13:1-28.

Janetski, Joel C., Mark L. Bodily, Bradley A. Newbold, and David T. Yoder

2012 The Paleoarchaic to Early Archaic Transition on the Colorado Plateau: The Archaeology of North Creek Shelter. American Antiquity 77:125-159.

Jochim, Michael A.

1988 Optimal Foraging and the Division of Labor. American Anthropologist 90:130-136.
Johansson, Lindsay D.

2013 The Buck or the Bunny? Documenting Change in Faunal Use through Time at North Creek Shelter. Paper presented at the 78th Annual Meeting of the Society for American Archaeology, Honolulu, Hawaii.

Kelly, Robert L.

1995a The Foraging Spectrum: Diversity in Hunter-Gatherer Lifeways. Smithsonian Institution, Washington, DC.

1995b Hunter-Gatherer Lifeways in the Carson Sink: A Context for Bioarchaeology. In Bioarchaeology of the Stillwater Marsh: Prehistoric Human Adaptation in the Western Great Basin, edited by Clark Spencer Larsen and Robert L. Kelly, pp. 12-32. Anthropological Papers 77. American Museum of Natural History, New York.

1997 Late Holocene Great Basin Prehistory. Journal of World Prehistory 11:1-50.

2014 Future Directions in Hunter-Gatherer Research: Technology. In The Oxford Handbook of the Archaeology and Anthropology of Hunter-Gatherers, edited by Vicki Cummings, Peter Jordan, and Marek Zvelebil, pp. 1110-1126. Oxford University Press, Oxford. DOI:10. 1093/oxfordhb/9780199551224.013.015.

Kinder, David H., Karen R. Adams, and Harry J. Wilson

2017 Solanum jamesii: Evidence for Cultivation of Wild Potato Tubers by Ancestral Puebloan Groups. Journal of Ethnobiology 37:218-240.

Larsen, Clark Spencer, and Dale L. Hutchinson

1999 Osteopathology of Carson Desert Foraging: Reconstructing Prehistoric Lifeways in the Western Great Basin. In Prehistoric Lifeways in the Great Basin Wetlands, edited by Brian E. Hemphill and Clark Spencer Larsen, pp. 184-202. University of Utah Press, Salt Lake City.

Larsen, Clark Spencer, and Robert L. Kelly (editors)

1995 Bioarchaeology of the Stillwater Marsh: Prehistoric Human Adaptation in the Western Great Basin. Anthropological Papers 77. American Museum of Natural History, New York.

Larsen, Clark Spencer, Christopher B. Ruff, and Robert L. Kelly

1995 Structural Analysis of the Stillwater Postcranial Human Remains: Behavioral Implications of Articular Joint Pathology and Long Bone Diaphyseal Morphology. In Bioarchaeology of the Stillwater Marsh: Prehistoric Human Adaptation in the Western Great Basin, edited by Clark Spencer Larsen and Robert L. Kelly, pp. 107-133. Anthropological Papers 77. American Museum of Natural History, New York.

Louderback, Lisbeth A.

2014 The Ecology of Human Diets during the Holocene at North Creek Shelter, Utah. PhD dissertation, Department of Anthropology, University of Washington, Seattle. Electronic document, https://digital.lib.washington.edu/researchworks/handle/1773/25980, accessed November 10, 2021.

Louderback, Lisbeth A., Judith Field, and Joel C. Janetski

2015 Curation Practices and Extraction Methods in Relation to Starch Grain Yields from Ground Stone Artifacts. Journal of Archaeological Sciences: Reports 4:535540. DOI:10.1016/j.jasrep.2015.10.011.

Louderback, Lisbeth A., Nicole M. Herzog, and Bruce M. Pavlik

2017 A New Approach for Identifying Starch Granules of Wild Food Plants from Arid Western North America. Starch - Stärke 68:1-7. DOI:10.1002/star.201600167. 
Louderback, Lisbeth A., Christopher A. Kiahtipes, and Joel C. Janetski

2020 Holocene Vegetation and Climate Change on the Colorado Plateau in Southern Utah, USA. Quaternary Research 94:1-15. DOI:10.1017/qua.2019.80.

Louderback, Lisbeth A., and Bruce M. Pavlik

2017 Starch Granule Evidence for the Earliest Potato Use in North America. PNAS 114:7606-7610. DOI:10. 1073/pnas.1705540114.

Lupo, Karen D., Dave N. Schmitt, and David B. Madsen 2020 Size Matters Only Sometimes: The Energy-Risk Trade-Offs of Holocene Prey Acquisition in the Bonneville Basin, Western USA. Archaeological and Anthropological Sciences 12:Article 160. DOI:10. 1007/s12520-020-01146-7.

Madsen, David B.

2007 The Paleoarchaic to Archaic Transition in the Great Basin. In Paleoindian or Paleoarchaic? Great Basin Human Ecology at the Pleistocene-Holocene Transition, edited by Kelly E. Graf and David N. Schmitt, pp. 3-20. University of Utah Press, Salt Lake City.

McCullagh, P., and John A. Nelder

1989 Generalized Linear Models. Chapman \& Hall/CRC, Boca Raton, Florida.

Morin, Eugène, Rebecca Bliege Bird, and Douglas Bird

2020 Mass Procurement and Prey Rankings: Insights from the European Rabbit. Archaeological and Anthropological Sciences 12:Article 262. DOI:10.1007/s12520020-01212-0.

Nagaoka, Lisa

2001 Using Diversity Indices to Measure Changes in Prey Choice at the Shag River Mouth Site, Southern New Zealand. International Journal of Osteoarchaeology 11:101-111. DOI:10.1002/oa.549.

Newbold, Bradley A.

2009 Paleoindian Lifeways of Paleoarchaic Peoples: A Faunal Analysis of Early Occupations at North Creek Shelter, Utah. Master's thesis, Department of Anthropology, Brigham Young University, Provo, Utah.

O'Connell, James F., and Kristen Hawkes

1981 Alyawara Plant Use and Optimal Foraging. In Hunter-Gatherer Foraging Strategies: Ethnographic and Archaeological Analyses, edited by Bruce Winterhalder and Eric A. Smith, pp. 99-125. University of Chicago Press, Chicago.

1984 Food Choice and Foraging Sites among the Alyawara. Journal of Anthropological Research. 40:504535.

O'Connell, James F., Kristen Hawkes, and Nick G. Blurton-Jones

1999 Grandmothering and the Evolution of Homo erectus. Journal of Human Evolution 36:461-485. DOI:10. 1006/jhev.1998.0285.

O’Connell, James F., Kevin T. Jones, and Steven R. Simms 1982 Some Thoughts on Prehistoric Archaeology in the Great Basin. In Man and Environment in the Great Basin, edited by David B. Madsen and James F. O'Connell, pp. 227-240. Papers 2. Society for American Archaeology, Washington, DC.

Pinson, Ariane $\mathrm{O}$.

2007 Artiodactyl Use and Adaptive Discontinuity across the Paleoarchaic/Archaic Transition in the Northern Great Basin. In Paleoindian or Paleoarchaic? Great Basin Human Ecology at the Pleistocene-Holocene Transition, edited by Kelly E. Graf and David
N. Schmitt, pp. 287-203. University of Utah Press, Salt Lake City.

Popper, Virginia S.

1988 Selecting Quantitative Measurements in Paleobotany. In Current Paleoethnobotany, Analytical Methods, and Cultural Interpretations of Archaeological Plant Remains, edited by Christine Hastorf and Virginia Popper, pp. 53-71. University of Chicago Press, Chicago.

$\mathrm{R}$ Core Team

2019 R: A Language and Environment for Statistical Computing. R Foundation for Statistical Computing, Vienna, Austria. Electronic document, https://www.Rproject.org/, accessed January 2021.

Rhode, David

2003 Coprolites from Hidden Cave Revisited: Evidence for Site Occupation History, Diet, and Sex of Occupants. Journal of Archaeological Science 30:909-922. DOI:10.1016/S0305-4403(02)00270-4.

Rhode, David, and Lisbeth A. Louderback

2007 Dietary Plant Use in the Bonneville Basin during the late Pleistocene-Holocene Transition. In Paleoindian or Paleoarchaic? Great Basin Human Ecology at Pleistocene/Holocene Transition, edited by Kelly E. Graf and David N. Schmitt, pp. 231-247. University of Utah Press, Salt Lake City.

Rhode, David, David B. Madsen, and Kevin T. Jones

2006 Antiquity of Early Holocene Small Seed Consumption and Processing at Danger Cave, Utah, USA. Antiquity 80:328-339. DOI:10.1017/S0003598X00093650.

Rhode, David, and Allise A. Rhode

2015 Energetic Return Rates from Limber Pine Seeds. Journal of California and Great Basin Anthropology 35:291-304.

Sassaman, Kenneth E.

1992 Lithic Technology and the Hunter-Gatherer Sexual Division of Labor. North American Archaeologist 13:249-262.

Schmitt, Dave N., and Karen D. Lupo

2012 The Bonneville Estates Rockshelter Rodent Fauna and Changes in Late Pleistocene-Middle Holocene Climates and Biogeography in the Northern Bonneville Basin, USA. Quaternary Research 78:95-102. DOI:10. 1016/j.yqres.2012.02.004.

Schoener, Thomas W.

1971 Theory of Feeding Strategies. Annual Review of Ecology and Systematics 2(1):369-404. DOI:10.1146/ annurev.es.02.110171.002101.

Schoeninger, Margaret J.

1995 Dietary Reconstruction in the Prehistoric Carson Desert: Stable Carbon and Nitrogen Isotopic Analysis. In Bioarchaeology of the Stillwater Marsh: Prehistoric Human Adaptation in the Western Great Basin, edited by Clark Spencer Larsen and Robert L. Kelly, pp. 96106. Anthropological Papers 77. American Museum of Natural History, New York.

1999 Prehistoric Subsistence Strategies in the Stillwater Marsh Region of the Carson Desert. In Prehistoric Lifeways in the Great Basin Wetlands, edited by Brian E. Hemphill and Clark Spencer Larsen, pp. 151-166. University of Utah Press, Salt Lake City.

Simms, Steven R.

1987 Behavioral Ecology and Hunter-Gatherer Foraging: An Example from the Great Basin. BAR International Series 381. British Archaeological Reports, Oxford. 
2008 Ancient Peoples of the Great Basin and Colorado Plateau. Left Coast Press, Walnut Creek, California.

Smith, Craig S., and William Martin

2001 Sego Lilies and Prehistoric Foragers: Return Rates, Pit Ovens, and Carbohydrates. Journal of Archaeological Science 28:169-183. DOI:10.1006/jasc.2000.0554.

Smith, Craig S., and Lance M. McNees

2005 Cymopterus bulbosus and Prehistoric Foragers: Patch Size, Plant Density, and Return Rates. Journal of Ethnobiology 25:1-23. DOI:10.2993/0278-0771 (2005)25[1:CBAPFP]2.0.CO;2.

Stephens, David W., and John R. Krebs

1986 Foraging Theory. Princeton University Press, Princeton, New Jersey.

Ugan, Andrew, and Jeffrey Rosenthal

2016 Brodiaea Return Rates and Their Ethnographic and Archaeological Implications for Occupations of the Northwestern Mojave Desert of North America. Journal of California and Great Basin Anthropology 36:73-90.

Weiss, Ehud, Wilma Wetterstrom, Dani Nadel, and Ofer BarYosef

2004 The Broad Spectrum Revisited: Evidence from Plant Remains. PNAS 101:9551-9555. DOI:10.1073/pnas. 0402362101

Welsh, Stanley L., N. Duane Atwood, Sherel Goodrich, and Larry C. Higgins (editors)
2015 A Utah Flora. 4th ed. Monte L. Bean Life Science Museum, Brigham Young University, Provo. Utah.

Winterhalder, Bruce, and Eric A. Smith

1992 Evolutionary Ecology and the Social Sciences. In Evolutionary Ecology and Human Behavior, edited by Eric A. Smith and Bruce Winterhalder, pp. 3-24. Aldine deGruyter, New York.

Withers, Kim, and Jim I. Mead

1993 Late Quaternary Vegetation and Climate in the Escalante River Basin on the Central Colorado Plateau. Great Basin Naturalist 53:145-161.

Wood, Brian, M., Jacob A. Harris, David A. Raichlen, Herman Pontzer, Katherine Sayre, Amelia Sancilio, Colette Berbesque, et al.

2021 Gendered Movement Ecology and Landscape Use in Hadza Hunter-Gatherers. Nature Human Behaviour 5:436-446. DOI:10.1038/s41562-020-01002-7.

Zeanah, David W.

2004 Sexual Division of Labor and Central Place Foraging: A Model for the Carson Desert of Western Nevada. Journal of Anthropological Archaeology 23:132. DOI:10.1016/S0278-4165(03)00061-8.

Submitted April 24, 2021; Revised July 12, 2021; Accepted September 23, 2021 